Interdisciplinary Research in Education

Volume 5, Issue $1 \&$ 2, 2020: 145-158

DOI: https://doi.org/10.3126/ire.v5i1\&2.34745

\title{
कक्षा दशको नेपाली भाषा पाठ्यपुस्तकमा बोलाइ सिपको अभ्यास
}

\author{
उमेश काफ्ले \\ umeshkafle4@gmail.com \\ उपप्राध्यापक \\ शिक्षाशास्त्र केन्द्रीय विभाग \\ त्रिभुवन विश्वविद्यालय
}

\begin{abstract}
लेखसार
भाषा पाठ्यपुस्तकमा राखिएका नमुना अभ्यासले विद्यार्थीहरूको भाषिक सिप विकासमा महत्त्वपूर्ण भूमिका निर्वाह गर्दछ। २०७४ मा प्रकाशित कक्षा दशको नेपाली पाठ्यपुस्तकमा उपयोग गरिएका बोलाइ सिपअन्तर्गतका अभ्यासहरूको पहिचान गर्नु यस अध्ययनको मुख्य उद्देश्य हो। यस अध्ययनका लागि पुस्तकालयबाट भाषा पाठ्यक्रम, पाठ्यपुस्तक र परीक्षणसम्बन्धी पुस्तकहरू सड्कलन गरिएको छ। परीक्षणसम्बन्धी पुस्तकबाट बोलाइ सिपसम्बद्ध मान्यताहरूको समीक्षात्मक टिप्पणीबाट विश्लेष्य सूचकहरू निर्धारण गरी अभ्यासको अध्ययन गरिएको छ। बोलाइ सिपसम्बद्ध अभ्यासहरू २२. ७५ प्रतिशत रहेको देखिन्छ। समग्रमा उच्चारण, शब्दार्थ र वाक्यमा प्रयोग, छलफल, विचार/तर्क, कुराकानी, संवाद, अभिनय, मौखिक प्रश्नोत्तर आदि क्षेत्रसंग सम्बद्ध अभ्यासहरू राखिएको छ। प्रत्येक पाठमा उच्चारण, शब्दार्थ र वाक्यमा प्रयोग तथा छलफलसम्बन्धी प्रश्नहरूको प्रयोग बढ़ी गरिएको छ। पाठगत अभ्यासको आधारमा हेर्दा चित्रवर्णन, शाब्दिक निबन्ध, मौखिक प्रश्नोत्तर आदि पक्षका अभ्यासहरू अत्यन्त कम रहेका छन्। बोलाइ सिपको प्रभावकारी विकासका लागि अन्तर्वार्ता, भूमिका निर्वाह, मौखिक रचना, वादविवाद र विषयअनुकूलका कुराकानी सम्बद्ध अभ्यास थच्नुपर्ने देखिन्छ। यस अध्ययनले शिक्षण सिकाइका कममा भाषा शिक्षकलाई बोलाइ सिपसम्बन्धित अभ्यासको पहिचान गरी समानुपातिक रुपले कक्षा कार्यकलाप अगाडि बढाउन सहयोगी हुनेछ। यस लेखले भाषा शिक्षणसम्बन्धी चासो राख्ने पाठ्यक्रम निर्माता, पाठ्यपुस्तक लेखक, भाषा शिक्षक र विद्यार्थीमा सहयोग पुचाउने छ।
\end{abstract}

मुख्य शब्दावली : उच्चारणगत, नमुना अभ्यास, प्रश्नोत्तर, बोधात्मक, भाषिक सिप ।

\section{परिचय}

भाषिक सिपहरूको सक्षमता प्राप्ति तथा क्षमता प्रदर्शनको सुनिश्चितताका लागि भाषा शिक्षण गरिन्छ । भाषा शिक्षणको आधिकारिक स्रोत सामग्री भाषा पाठ्यपुस्तक हो। भाषा पाठ्यक्रमको आधारमा पाठ्यपुस्तक निर्माण गरिन्छ। विद्यालयीय शिक्षणका लागि देशैभर एकै प्रकृतिको पाठ्यपुस्तक उपयोगमा ल्याइएको छ, 
पाठ्यपुस्तकमा विद्यार्थीको क्षमता, रुचि तहअनुसारका साहित्यिक र साहित्येतर सामग्री समेटिएको हुन्छ। यसमा पाठअनुकूल सिपकेन्द्रित नमुना अभ्यासहरूको संयोजन गरिन्छ। यस्ता अभ्यासले विद्यार्थीमा प्रशस्त भाषिक क्षमता वृद्धि हुने अपेक्षा राखिन्छ। नेपाली भाषा शिक्षणका सन्दर्भमा जयपृथ्वीबहादुर सिंहको । अक्षराङ्क शिक्षा' (१९५ॅ) लाई पहिलो आधिकारिक भाषापाठ्यपुस्तक मानिन्छ। यद्यपि यो पुस्तक भाषा शिक्षणको उद्देश्यले भने तयार गरिएको थिएन। यसपछि, नेपाली विषयको पठनपाठनमा परिवर्तनका खुट्किला थपिंदै गए। विशेषतः राष्ट्रिय शिक्षा पद्धतिको योजना २०२६ लागु भएपछि पाठ्यक्र र पाठ्यपुस्तक निर्माण र लेखनमा नवीन रूप सिर्जना भयो। यसपछि, २०३६, २०४५, २०६४ हुँदै २०७३ सम्म पाठ्यपुस्तक लेखन र विकासमा थुप्रै परिवर्तनहरू देखिएका छन्।

वर्तमान कक्षा १० को नेपाली पाठ्यपुस्तक माध्यमिक शिक्षा पाठ्यक्रम - २०७१ को आधारमा तयार गरिएको हो। भाषा पाठ्यपुस्तकले विद्यार्थीमा बोध र अभिव्यक्ति सिपको विकास गर्दछ। पाठ्यपुस्तकले भाषाका सुनाइ, बोलाइ, पढाइ र लेखाइ सिपलाई उत्तिकै महत्त्व दिनुपर्ने हुन्छ। भाषाको बोध क्षमताभित्र सुनाइ र पढाइ सिप पर्दछ् भने अभिव्यक्ति क्षमताभित्र बोलाइ र लेखाइ सिप पर्दछ् । भाषा सिकारु वा प्रयोगकर्ताले भाषिक ज्ञान प्राप्ति गरे वा गरेनन् भनेर मापन गर्नाका लागि सिपगत प्रस्तुतीकरणमा प्राथमिकता दिइन्छ। वाह्य प्रस्तुतीकरणका सिप भनेको बोलाइ र लेखाइ हुन् । यसर्थ बोलाइ र लेखाइ सिपको परीक्षणबाट नै सुनाइ र पढाइको जाँच गर्न सकिन्छ । वर्तमान कक्षा १० को नेपाली भाषा पाठ्यपुस्तकमा चारवटै सिपका अभ्यासलाई अलग अलग राखिएको छ।

भाषा शिक्षणलाई दिगो र प्रभावकारी बनाउन नमुना अभ्यासको महत्त्वपूर्ण भूमिका रहेको छ। भाषा प्रयोगमा अभ्यास र बुद्धिको संयोजन रहन्छ। व्यवहारवादीले भाषाको प्रयोगमा अभ्यास, वातावरण, पुनर्बल आदिलाई मुख्य मान्दछ् भने मनोवादीले भाषाको सिकाइका लागि व्यक्तिगत क्षमतालाई मुख्य आधार मान्दछ् । यिनीहरूले सीमित नियमका आधारमा असीमित उत्पादन क्षमता बढाउनुपर्नेमा जोड दिन्छन् । सिद्धान्तमा जस्तो प्रयास भए पनि विद्यालय तहमा प्रत्यक्ष वा अप्रत्यक्ष रूपमा अभ्यासको आवश्यकता मानिने गरिएको छ। पाठ्यपुस्तकमा राखिएका सिपगत अभ्यासमध्ये सुनाइ र बोलाइलाई बढी प्रयोगात्मक मानिन्छ । माध्यमिक शिक्षा पाठ्यक्रम २०७१ ले पनि सुनाइ र बोलाइ सिपको परीक्षणका लागि २ू अड्कको प्रयोगात्मक कार्य/मूल्याड्कनका लागि छुट्याइएको छ। पाठ्यक्रमले प्रयोगात्मक कार्यअन्तर्गत सुनाइ र बोलाइ मापनमा आधारित प्रश्नहरू सोधी विद्यार्थीको सुनाइ र बोलाइ सिपको परीक्षण गर्नुपर्ने कुरा उल्लेख गरेको छ। यसर्थ पाठ्यक्रमको अपेक्षा परिपूर्ति गर्ने मुख्य भूमिका पाठ्यपुस्तकमा रहन्छ। पाठ्यपुस्तकमा पृथकीकृत रूपमा राखिएको सिपगत अभ्यासमध्ये बोलाइ सिपको अभ्यास के कस्तो रहेको छ भन्ने विषय नै यस अध्ययनको मुख्य मुद्दा हो। अभ्यासमा राखिएका विविध प्रश्नहरूबाट विद्यार्थीको बोलाइ सिपको विकास हुन सक्छ, कि सक्दैन भन्ने रिक्तताको पहिचानको आधारमा अध्ययनलाई तार्किक र प्रामाणिक बनाउनका लागि यो अध्ययन गरिएको हो । यो अध्ययन २०७४ मा प्रकाशित नेपाली पाठ्यपुस्तकमा आधारित छ। 
कक्षा दशको नेपाली भाषा पाठयपुस्तकमा बोलाइ सिपको अभ्यास/ 147

\section{अध्ययनको उद्देश्य}

पाठ्यक्रमको अपेक्षालाई पूरा गर्ने उद्देश्यले पाठ्यपुस्तकहरू तयार गरिन्छन् । शिक्षणका सन्दर्भमा भाषा पाठ्यपुस्तकले अभ्यासात्मक गतिविधि सज्चालन र भाषिक सिपको विकासमा सहयोग पुज्याउने अपेक्षा गरिन्छ। पाठ्यपुस्तकमा भाषिक सिपमा सक्षमता ल्याउने परिकल्पनाबाट अभ्यासहरू राखिएका हुन्छन् । सबै अभ्यासले भाषामा केकति सहयोग पुच्याउँछ् भन्ने पक्षमा चासो रहनु स्वाभाविक पनि हो। कक्षा दशको वर्तमान नेपाली भाषा पाठ्यपुस्तकको नमुना अभ्यासअन्तर्गत बोलाइ सिपसम्बद्ध अभ्यासको पहिचान र त्यसको भूमिकाको व्याख्या गर्नु नै यस अध्ययनको उद्देश्य हो। त्यस्तैगरी यस लेखमा कक्षा दशको नेपाली पाठ्यपुस्तकमा राखिएका नमुना अभ्यासमध्ये बोलाइ सिपसम्बद्ध अभ्यासको विविधता र त्यसको संयोजन पहिचान गर्ने उद्देश्य राखिएको छ।

\section{पूर्वकार्यको पुनरावलोकन}

यस अध्ययनमा पाठ्यपुस्तकमा प्रयुक्त बोलाइ सिपको परीक्षण र विकासमा सहयोगी हुने विभिन्न विद्वान् हरूको विचारलाई पूर्वकार्यको रूपमा लिइएको छ। अभ्यासहरूलाई विद्यार्थीको भाषिक सिपको विकास र परीक्षणको महत्त्वपूर्ण आधार मानिन्छ। यसर्थ यहाँ बोलाइ सिपको परीक्षणका लागि के कस्ता प्रश्न अभ्यासमा राख्न सकिन्छ भनेर गरिएका अध्ययनको समीक्षा गरिएको छ।

ल्याडो (सन् १९६४) द्वारा तयार पारिएको ‘ल्याड्ग्वेज टेस्टिड' पुस्तकमा बोलाइ सिपको परीक्षणका लागि आवश्यक पद्धतिको चर्चा गरिएको छ। बोलाइ क्षमताको परीक्षणका लागि सामान्य प्रविधिअन्तर्गत मौखिक उच्चारणमा विशेष जोड दिइएको छ। यो भाषा सिकारुको तत्कालीन र तीव्र प्रतिक्रियासँग सम्बन्धित हुन्छ। यसमा विशेषतः उच्चारण पक्षलाई हेरिन्छ। विशिष्ट प्रविधिअन्तर्गत चित्र वा अन्य पक्षका आधारमा उच्चारण, व्याकरणात्मक संरचना र शब्दभण्डारको परीक्षण गरिने कुरा उल्लेख गरिएको छ। मौखिक उत्पादनसम्बद्ध परीक्षण ढाँचाका लागि चित्र शृड्खला, सम्प्रेषणात्मक बोली, कुराकानी आदिलाई आधार मानिन्छ। बोलाइ सिपका केही पक्षलाई वस्तुपरक ढड्गले परीक्षण गर्न सकिन्छ। सामूहिक छलफल मार्फत बोलाइ सिपको परीक्षण गर्न सकिने कुरा उल्लेख गरिएको छ। बोलाइ सिप परीक्षणको मुख्य आधार उच्चारण, चित्र वर्णन, व्याकरणात्मक, संरचना, शब्दभण्डार, कुराकानी र सामूहिक छलफललाई मानिएको छ। अध्ययनीय आधार पहिचानका लागि यस अध्ययनले सहयोग पुच्याउँछ।

वाइर (सन् 9९६द) द्वारा ‘कम्युनिकेटिभ ल्याङ्ग्वेज टेस्टिङ’ पुस्तक तयार पारिएको छ। यो पुस्तकमा भाषिक सिपहरूको परीक्षणीय आधारलाई अनुसन्धानात्मक रूपमा प्रस्तुत गरिएको छ। यसमा बोलाइ सिपको परीक्षणलाई सम्प्रेषणात्मक प्रतिमानबाट हेरिएको छ। उद्देश्यपूर्ण, उत्प्रेरणायुक्त र रुचिपूर्ण हुने कारण शिक्षण सिकाइमा यस्तो शिक्षणबाट सकारात्मक पृष्ठमार्जन हुने पक्ष वर्णन गरिएको छ। बोलाइ क्षमताको परीक्षणका लागि शाब्दिक निबन्ध, स्वतन्त्र अन्तर्वार्ता, नियन्त्रित अन्तर्वार्ता, सूचना स्थानान्तरण (प्रश्नात्मक रूपमा चित्रवर्णन), अन्तर्क्रियात्मक कार्य, भूमिका निर्वाह, मौखिक परीक्षा र एकीकृत परीक्षणको अवलम्बन गर्न सकिने सोदाहरण वर्णित छ। उपर्युक्त सैद्धान्तिक पक्षका आधारमा कक्षा दशको नेपाली पाठ्यपुस्तकको बोलाइ सिपअन्तर्गतका नमुना अभ्यासको विश्लेष्य ढाँचा तयार पार्न सघाउ पुगेको छ। 
हिटन (सन् १९९०) द्वारा 'राइटिङ इड्लिस ल्याङ्ग्वेज टेस्ट्स' पुस्तक तयार पारिएको छ । यसमा मौखिक अभिव्यक्ति परीक्षणसम्बन्धी पक्षहरू राखिएको छ। बोलाइ सिपलाई परीक्षणको कठिनाइपूर्ण स्थिति मानिएको छ, किनकि बोलाइ सिपको परीक्षणीय मानदण्ड किटान गर्न र त्यसको तत्काल उपयोग गर्न धेरै समस्या हुन सक्ने कुरा उल्लेख गरिएको छ। बोलाइ सिपको परीक्षणका लागि उच्चारण, अन्तरपरिवर्त्य कुराकानी, चित्र वर्णन, मौखिक अन्तर्वार्ता, संक्षिप्त कुराकानी, समूह छलफल र भूमिका निर्वाह तथा संक्षिप्त समस्या समाधानका कार्यकलाप गर्न सकिने उल्लेख गरिएको छ। यसर्थ बोलाइ सिपसम्बन्धी उपर्युक्त पक्षलाई आधार मानी कक्षा दशको नेपाली पाठ्यपुस्तकमा बोलाइ सिपसँग सम्बद्ध अभ्यासको विश्लेषण गर्ने प्रयास गरिएको छ।

ब्रोवन (सन् २००४) ले 'ल्याड्ग्वेज एसेस्मेन्ट’ पुस्तकमा बोलाइ सिपको परीक्षण सम्बन्धी आधारहरू तय गरेका छन् । बोलाइ सिपको परीक्षणका लागि प्रत्यक्ष प्रतिक्रिया कार्य, मौखिक प्रश्नोत्तर, चित्रवर्णन, अनुवाद (ससाना सड्कथन), भावार्थ वर्णन, अन्तर्वार्ता, भूमिका निर्वाह, छलफल र कुराकानी, मौखिक प्रस्तुतीकरण, कथाकथन आदि पक्षको उपयोग गर्न सकिने उल्लेख गरिएको छ। उल्लिखित पक्षले बोलाइ सिपको विश्लेषणका लागि आधार तय गर्न सहयोग पुग्ने देखिन्छ।

पौडेल (२०६४) द्वारा 'भाषिक मूल्याङ्कनका प्रयोगात्मक सन्दर्भहरू' लेख तयार गरिएको छ। यस लेखमा ग्रहण र अभिव्यक्ति सिपका प्रयोगपरक मूल्याङ्कनीय सन्दर्भहरूलाई विस्तृत रूपमा वर्णन गरिएको छ। अभिव्यक्ति सिपका प्रयोगपरक मूल्याङ्कनीय सन्दर्भहरूलाई कथन र लेखन सिपका रूपमा विभाजन गरिएको छ। कथन सिपका प्रयोगपरक मूल्याङ्कनीय सन्दर्भहरूमा वैयक्तिक कथन, लयात्मक अभिव्यक्ति, सामूहिक वा अन्तर्क्रियात्मक कथन, मौखिक वर्णन र विविध पर्दछ् । वैयक्तिक कथनमा निर्देशन, उद्घोषण, वक्तृता भाषण, मनोलिपि, कथाकथन, चुट्किला तथा विनोदात्मक कथन, परिचयात्मक कथन (वस्तु, व्यवसाय, संस्था, व्यक्ति आदि), बुँदा अथवा निचोड कथन, योजना, भावना, कल्पना, अनुमान आदि कथन, मौखिक प्रतिवेदन, समीक्षा, टिप्पणी, विश्लेषण वा मूल्याड्कनात्मक कथन पर्ने कुरा उल्लेख गरिएको छ। गीत कविता र गजल गायनलाई लयात्मक अभिव्यक्ति भित्र राखिएको छ। सामूहिक वा अन्तर्क्रियात्मक कथनअन्तर्गत कुराकानी, गफ, भलाकुसारी, छलफल, संवाद, तार्किक वा विवादात्मक कथन, सल्लाह वा सम्भौता र प्रश्नोत्तर पर्दछन्। मौखिक वर्णनमा रुचि अथवा चाहना पारिवारिक पेसा वा दिनचर्या, वैयक्तिक पेसा वा दिनचर्या, सामुदायिक पेसा वा दिनचर्या, सामाजिक, सांस्कृतिक, प्राकृतिक परिवेश वा व्यवहार, घटना, समाचार वा सूचना, चित्र, दृश्य अथवा नक्सा वर्णन पर्ने तथ्य अगाडि सारिएको छ। जाँचसूची र श्रेणीमापकका आधारमा भाषिक सिपको प्रयोगात्मक मूल्याङ्कन गर्न सकिने कुरा अवलोकन फारामसहित प्रस्तुत गरिएको छ। यस लेखले प्रयोगात्मक सिपको लागि आधार तय गरी बोलाइ सिपका अभ्यासको विश्लेषण मद्दत गर्ने देखिन्छ।

अधिकारी (२०६७) द्वारा 'नेपाली भाषा शिक्षण' पुस्तकमा भाषिक सिपको परीक्षण : केही विशेष टिपोट शीर्षकमा बोलाइ सिपको परीक्षणसम्बन्धी मान्यता प्रस्तुत गरिएको छ। यसमा उच्चारण, सस्वरपठन र मौखिक रचना मार्फत बोलाइ सिपको परीक्षण गर्न सकिने उल्लेख गरिएको छ। मौखिक रचनाअन्तर्गत 
चित्र वर्णन, कथा वा घटनावर्णन, समसामयिक घटना वा समस्याबारे अभिव्यक्तिका साथसाथै वादविवाद, संवाद, छलफल आदि कार्यमार्फत शिक्षार्थीहरूको सहभागिताको पर्यवेक्षण गरी परीक्षण गरिने आधारहरू देखाइएको छ। बोलाइ सिपको परीक्षणको लागि निकै समय र विशेष दक्षता आवश्यक पर्ने कुरा पनि उल्लेख गरिएको छ। उल्लिखित सैद्धान्तिक आधार उपयोग गरी कक्षा दशको नेपाली पाठयपुस्तकमा अन्तर्निहित बोलाइ सिपका अभ्यासको विश्लेषण गरिएको छ।

\section{विश्लेषणात्मक ढाँचा}

यस अध्ययनका लागि माथि प्रस्तुत गरिएका ल्याडो (सन् १९६४), हिटन (सन् १९९०), वाइर (सन् १९६द), ब्रोवन (सन् २००४) र अधिकारी (२०६७) का विचार तथा नेपाली भाषा पाठ्यक्रम र पाठ्यपुस्तकसम्बन्धी मान्यतालाई आत्मसात् गरी विश्लेषणका लागि निम्नलिखित ढाँचाको अवलम्बन गरिएको छ,

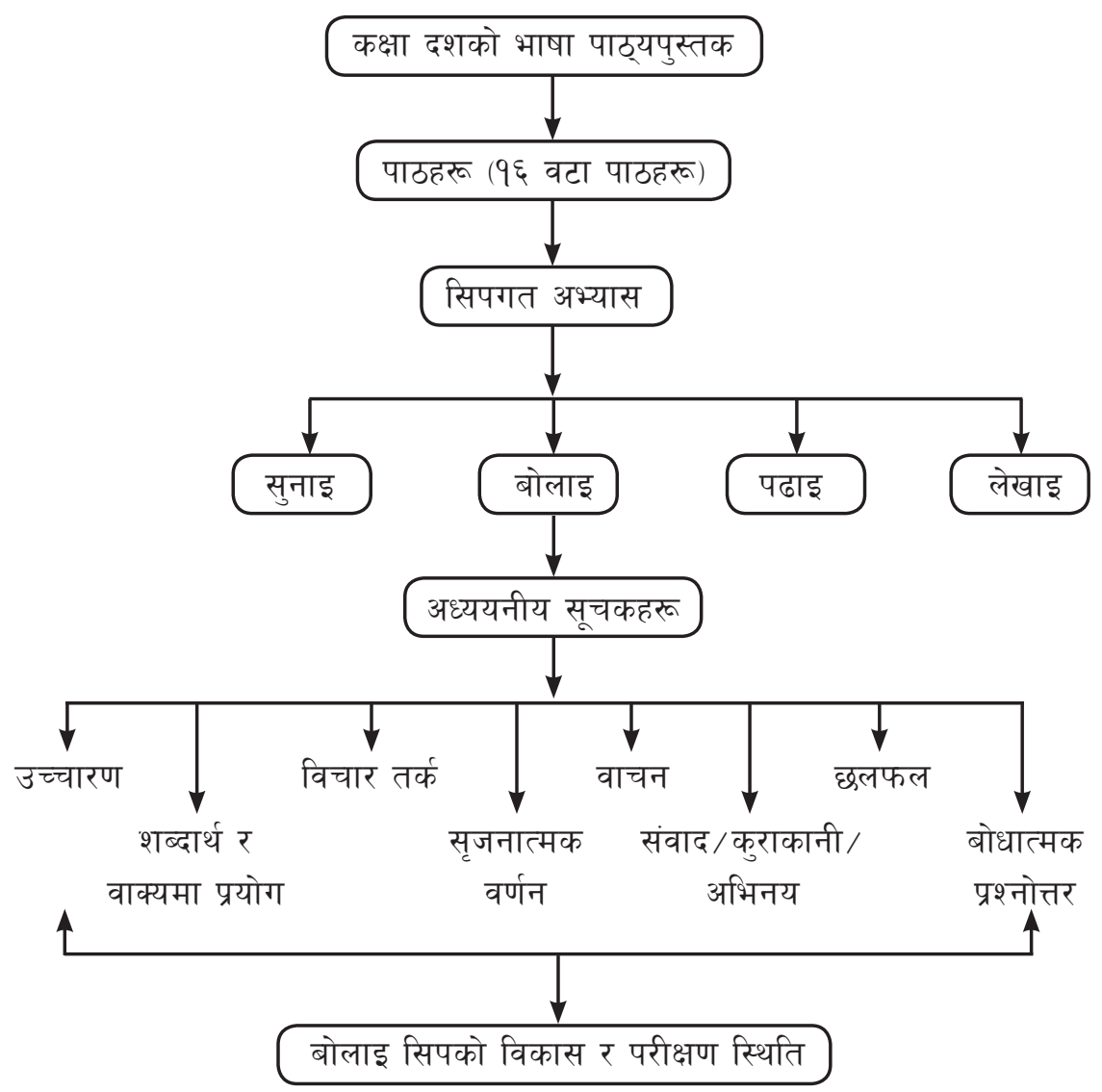

\section{अध्ययन विधि}

प्रस्तुत अध्ययनका लागि भाषा पाठ्यक्रम, पाठ्यपुस्तक र परीक्षणसम्बन्धी पुस्तकहरू सड्कलन गरिएको छ। परीक्षणसम्बन्धी पुस्तकबाट बोलाइ सिपसम्बद्ध मान्यताहरूको समीक्षात्मक टिप्पणी गरी विश्लेष्य सूचकहरू निर्धारण गरिएको छ। यस अध्ययनको प्रमुख स्रोत सामाग्री नेपाली कक्षा १० पाठ्यपुस्तक 
(२०७४) हो। कक्षा दशको भाषा पाठ्यपुस्तकको नमुना अभ्यासअन्तर्गत बोलाइ सिपमा रहेका अभ्यासात्मक प्रश्नहरूको टिपोट र सूचीकरण मार्फत सामग्री सड्कलन गरिएको छ। सड्कलित सामग्रीलाई पूर्वकार्यको अध्ययनबाट निर्धारण गरिएका सूचकहरूको आधारमा तालिकीकरण गर्दे आवश्यकताको आधारमा प्रतिशत वा सोदाहरण शाब्दिक व्याख्या विश्लेषण गरी देखाइएको छ।

\section{परिणाम तथा छलफल}

प्रस्तुत अध्ययन नेपाली कक्षा १० (२०७४) को नमुना अभ्यासअन्तर्गत बोलाइ सिपगत अभ्यासमा केन्द्रित छ। बोलाइ सिपको विकास र परीक्षण गर्ने उद्देश्यले राखिएका अभ्यासहरूको अवस्था र तिनीहरूको उपस्थितिले देखाउने प्रवृत्तिहरूलाई निर्धारित सूचकहरूको आधारमा व्याख्या विश्लेषण गरिएको छ। पाठ्यपुस्तकमा पाठ 9 जन्मभूमि, पाठ $₹$ सन्तुष्टि, पाठ ३ सन्दुक रुइत, पाठ $\gamma$ थाड्का, पाठ $y$ म पनि सक्छु, पाठ ६ व्यापारिक चिठी, पाठ $७$ प्रत्यागमन, पाठ $५$ वर्षा, पाठ $९$ हाम्रो संस्कृति, पाठ १० स्थानीयकरणभन्दा व्यापारीकरण बेस,पाठ ११ लक्ष्मीपूजा, पाठ १२, क्लारा जेटकिन, पाठ १३ जय भुँडी, पाठ १४ म सडक बोल्दै छु, पाठ १४ टीका र पाठ १६ माउजड बाबुसाहेबको कोट रहेका छन्। यहाँ विश्लेषणका सन्दर्भमा पाठको नाम नलेखी सड्ख्या मात्र किटान गरिएको छ। सिपगत अभ्यासलाई मुख्य आधार मानी निम्नानुसार विश्लेषण गर्न सकिन्छ :

\section{समग्रमा भाषिक सिपगत अभ्यास}

कक्षा दशको भाषा पाठ्यपुस्तकमा सुनाइ, बोलाइ, पढाइ र लेखाइ सिपका अभ्यासलाई अलग अलग रूपमा राखिएको छ। यस अध्ययनको मुख्य क्षेत्र बोलाइ सिपको अभ्यास विश्लेषण भए पनि अध्ययनीय स्पष्टताको लागि सबै सिपहरूको समग्र स्थितिलाई निम्नानुसार देखाउन सकिन्छ :

तालिका 9

सिपगत अभ्यासको समग्र स्थिति

\begin{tabular}{|c|c|c|c|c|c|c|c|c|}
\hline \multicolumn{8}{|c|}{ भाषिक सिप } & \multirow{3}{*}{ जम्मा } \\
\hline \multicolumn{2}{|c|}{ सुनाइ } & \multicolumn{2}{|c|}{ बोलाइ } & \multicolumn{2}{|c|}{ पढाइ } & \multicolumn{2}{|c|}{ लेखाइ } & \\
\hline सड़ख्या & प्रतिशत & सङ्ख्या & प्रतिशत & सङख्या & प्रतिशत & सङख्या & प्रतिशत & \\
\hline$y \gamma$ & $95 . ३ \xi$ & $\xi \vartheta$ & २२. जद & $\xi \xi$ & २9.4र & 990 & ३७. ४৭ &  \\
\hline
\end{tabular}

स्रोत : नेपाली कक्षा १०, २०७४

तालिका 9 मा भाषिक सिपहरूको समग्र स्थिति देखाइएको छ। कक्षा दशको भाषा पाठ्यपुस्तकले सबैभन्दा बढी अभ्यास लेखाइ सिपका लागि छुट्याइएको छ। सबैभन्दा कम अभ्यास सुनाइ सिपको छ। बोलाइ र पढाइ सिपको अभ्यास प्रस्तुतिमा लगभग समानता देखिन्छ। अभ्यासहरूको समानान्तर प्रस्तुतिमा सन्तुलन कायम हुन सकेको छैन। विद्यार्थीको भाषिक सिप विकासमा नमुना अभ्यासको महत्त्वपूर्ण भूमिका रहने कारण सबै सिप विकास हुने गरी संयोजन गर्नु उपयुक्त हुन्छ। माध्यमिक शिक्षा पाठ्यक्रमले सुनाइ र बोलाइ सिप परीक्षणका लागि २४ अड्कको प्रयोगात्मक मूल्याङ्कनको व्यवस्था पनि गरेको छ। यस आधारमा हेर्दा २२. ७६ प्रतिशत बोलाइ सिपसम्बद्ध अभ्यास ठिकै मान्न सकिन्छ। सैद्धान्तिक मूल्याङ्कनलाई 
कक्षा दशको नेपाली भाषा पाठयपुस्तकमा बोलाइ सिपको अभ्यास/ 151

टेवा पुच्याउने उद्देश्यले लेखाइ सिपका अभ्यास बढी राखिएको हुन सक्छ तर विद्यार्थीको समग्र भाषिक व्यवहारमा सक्षमता कायम गर्न सबै सिपलाई समान महत्त्व दिनु उपयोगी हुन्छ।

\section{उच्चारणसम्बन्धी अभ्यास}

कक्षा दशको भाषा पाठ्यपुस्तकमा बोलाइ सिपको अभ्यासअन्तर्गत सबै पाठहरूमा उच्चारणसम्बन्धी अभ्यासहरू राखिएका छन् । शुद्ध उच्चारणको अभ्यास राख्दा दुई प्रवृत्तिलाई आत्मसात् गरिएको छ। एकथरीका अभ्यासमा शुद्ध उच्चारण गर्नुहोस् भनिएको छ भने अर्कोथरीका अभ्यासमा उदाहरणमा देखाएजस्तै गरी उच्चारण गर्नुहोस् भनिएको छ। यस किसिमको अभ्यासात्मक कार्यले भने अक्षरीकरणको मानक उच्चारणको मान्यतामा जोड दिन खोजेको देखिन्छ। पाठगत स्थितिका आधारमा उच्चारणसम्बन्धी अभ्यासको स्थितिलाई यसरी देखाइएको छ :

तालिका ?

उच्चारणगत अभ्यासको स्थिति

\section{पाठहरू}


सं. प्र. सं. प्र. सं. प्र. सं. प्र. सं. प्र. सं. प्र. सं. प्र. सं. प्र. सं. प्र. सं. प्र. सं. प्र. सं. प्र. सं. प्र. सं. प्र. सं. प्र. सं. प्र.

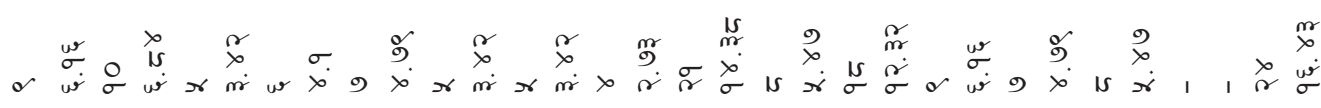

स्रोत : नेपाली कक्षा १०, २०७४

तालिका २ मा उच्चारणगत अभ्यासको स्थिति देखाइएको छ। पाठ १४ अर्थात् ‘टीका' एकाड्की बाहेक सबै पाठको बोलाइ सिपअन्तर्गत पहिलो प्रश्न उच्चारणसम्बन्धी रहेको छ। पाठ १६ (माउजड बाबुसाहेबको कोट) मा उच्चारणसम्बन्धी सबैभन्दा धेरै (१६.४३ प्रतिशत) शब्दहरू राखिएको छ। त्यसपछि पाठ ९ (हाम्रो संस्कृति) मा १४.३६ प्रतिशत उच्चारण शब्दहरू दिइएको छ। सबैभन्दा कम उच्चारण शब्द पाठ द (वर्षा) मा दिइएको छ। यस आधारमा हेर्दा लगभग २.७३ प्रतिशतदेखि १६. ४३ प्रतिशतसम्म उच्चारणगत शब्दहरू दिइएको छ। १२ वटा पाठहरूमा $७$ प्रतिशतभन्दा कम नै शब्दहरू उच्चारणको लागि राखिएको छ। यस आधारमा हेर्दा तीनवटा पाठबाहेकका पाठमा उच्चारणका लागि दिइएका शब्दमा लगभग समानताको स्थिति देखिन्छ। बोलाइ सिपको प्रारम्भिक आधार उच्चारण भएकाले सबै पाठहरूमा यससम्बन्धी अभ्यास राख्नु उपयुक्त हुन्छ। उदाहरण दिएर उच्चारण गर्न निर्देश गरिएका अभ्यास चाहिं विद्यार्थीका लागि प्रभावकारी हुने देखिन्छ : जस्तै:

टम्म : टम्. म, खर्पन : खर्. पन्.

बोलाइ सिपको प्रारम्भिक विकासको मुख्य आधार शुद्ध उच्चारण हो । सबै पाठहरूले यसलाई समेट्न सकेकाले उच्चारणगत अभ्यासका दृष्टिले पाठ्यपुस्तक उपयुक्त देखिन्छ। तथापि उच्चारणगत अभ्यासहरू दिँदा विद्यार्थीले गर्ने सम्भावित त्रुटि क्षेत्र सम्बोधन हुने गरी राख्नु प्रभावकारी हुन्छ। सबै अभ्यासले यस 
पक्षलाई समेट्न सकेको छैन। कक्षागत सिकाइ उपलब्धिअन्तर्गत शब्द र वाक्यमा प्रयुक्त स्वर र व्यज्जन वर्णहरू पहिचान गरी उच्चारण गर्न सक्ने उल्लेख गरिएको छ, तर अभ्यासमा स्वर र व्यज्जन वर्ण पहिचान सम्बन्धी अभ्यासात्मक कार्यकलाप राखिएको देखिंदैन।

\section{शब्दार्थ र वाक्यमा प्रयोगसम्बन्धी अभ्यास}

बोलाइ सिपको विकासका लागि मौखिक रूपमा शब्दको अर्थ भन्न वा वाक्यमा प्रयोग गराउन सकिन्छ । विद्यार्थीले बुक्केका वा पढेका आधारमा शब्दको अर्थ भन्न सक्छन् । विदेशी विद्वान्हरूले शब्दको अर्थ र वाक्यमा प्रयोगभन्दा पनि शाब्दिक निबन्धका रूपमा यसलाई प्रस्तुत गर्नुपर्ने दृष्टिकोण राखेका छन्। यसमा विद्यार्थीलाई कुनै शब्द सोधी त्यसका बारेमा दुई तीनवटा वाक्य मौखिक रूपमा भन्न लगाएर परीक्षण गर्न सक्ने स्थिति रहन्छ। हाम्रा पाठ्यपुस्तकहरूमा यस्ता अभ्यासहरूलाई खासै प्राथमिकता दिइएको छैन। शब्दार्थ र वाक्यमा प्रयोगसम्बन्धी अभ्यासको स्थितिलाई निम्नानुसार प्रस्तुत गर्न सकिन्छ :

तालिका ३

शब्दार्थ र वाक्यमा प्रयोगसम्बन्धी अभ्यासको स्थिति

\begin{tabular}{|c|c|c|c|c|c|c|c|c|c|c|c|c|c|c|c|c|c|c|}
\hline \multicolumn{19}{|c|}{ पाठ } \\
\hline & 9 & & $R$ & & ३ & & $\gamma$ & & $y$ & & $\rho$ & 9 & ३ & & $9 y$ & & $9 \xi$ & जम्मा \\
\hline सं. & प्र. & सं. & प्र. & सं. & प्र. & सं. & प्र. & सं. & प्र. & सं. & प्र. & सं. & प्र. & सं. & प्र. & सं. & प्र. & \\
\hline 92 &  & $\theta$ & ᄃ. ૪३ & $\gamma$ & $\gamma .59$ & 90 & 92.08 & $\xi$ & ९.२२ & २३ & २७.ง & $y$ & $\xi . ० 2$ & $y$ & $\xi .09$ & 99 & १३.२૫ & द३ \\
\hline
\end{tabular}

स्रोत : नेपाली कक्षा १०, २०७४

तालिका ३ मा शब्दार्थ र वाक्यमा प्रयोगसम्बन्धी अभ्यासको स्थितिलाई प्रतिशतमा देखाइएको छ। कक्षा दशको भाषा पाठयपुस्तकमा नौवटा पाठहरूमा बोलाइ सिप विकासका अभ्यास राखिएको छ, भने बाँकी सातवटा पाठमा यससम्बन्धी अभ्यासहरू राखिएको छैन। शब्दार्थ र वाक्यमा प्रयोगसम्बन्धी अभ्यास सबैभन्दा बढी पाठ नौ अर्थात् हाम्रो संस्कृतिमा देखिन्छ। सबैभन्दा कम (४.५ प्रतिशत) पाठ तीन अर्थात् सन्दुक रुइतमा भेटिएको छ। ४.५१ प्रतिशतदेखि २६.७१ प्रतिशतसम्म रहनुले शब्दार्थ र वाक्यमा प्रयोगसम्बन्धी अभ्यासमा एकरूपता रहेको देखिंदैन । शब्दको अर्थ भन्न लगाउँदा पाठकै पुच्छारमा अर्थ राखिएका वा नराखिएका दुबै प्रकृतिलाई आत्मसात् गरिएको छ। पाठ्यक्रमको अपेक्षालाई परिपूर्ति गर्ने गरी प्रश्न बनाउनका लागि विशिष्टीकरण तालिकाको उपयोग गरिन्छ। लिखित सिपको परीक्षणमा वाक्यमा प्रयोगका लागि अनुकरणात्मक, प्राविधिक/पारिभाषिक, उखान-टुक्का र निपात सोधनुपर्ने कुरा विशिष्टीकरण तालिकामा उल्लेख गरिएको छ। बोलाइ सिपकै आधारमा लेखाइ सिपको विकास हुने कारण बोलाइका लागि पनि त्यही प्रवृत्तिका शब्दहरू राख्दा राम्रो हुने देखिन्छ। बोलाइ सिपका लागि राखिएका वाक्यमा प्रयोगसम्बन्धी अधिकांश अभ्यासहरूमा प्राविधिक र पारिभाषिक शब्दलाई नै बढ़ी जोड दिइएको छ। भूपरिवेष्ठित, शल्यक्रिया, स्वर्णपदक, अपवाद, भुक्तानी, पेस्की, वाणिज्य, सहरीकरण, वाड्मय, प्रथा, दाइजो जस्ता शब्दहरू दिइएको छ। पाठ १३ र १४ मा हात्तीको मुखमा जिरा, हातमुख जोड्नु, गुनासो गर्नु, डाँडो काट्नु, दैलो कुर्नु, हंसले ठाउँ छोड्नु, कोही पोल्नु जस्ता टुक्काको अभ्यास राखिएको छ। विशिष्टीकरण 
कक्षा दशको नेपाली भाषा पाठयपुस्तकमा बोलाइ सिपको अभ्यास/ 153

तालिकालाई आधार मान्दा अनुकरणात्मक, उखान र निपातसम्बन्धी अभ्यासलाई मौखिक उत्पादनअन्तर्गत नराखिनु कमजोर पक्ष हो। यसर्थ शिक्षकले कक्षाकोठामा पाठ्यक्रमको अपेक्षा र विशिष्टीकरण तालिकाको मर्मलाई ख्याल गरी शिक्षण गर्नुपर्ने देखिन्छ।

\section{विचार वा तर्कसम्बन्धी अभ्यास}

बोलाइ सिपको विकासका लागि पाठगत विषयवस्तुसँग सम्बद्ध रहेका वा नरहेका विषयमा विद्यार्थीलाई आफ्ना विचार वा तर्क राख्न लगाउन सकिन्छ। कक्षा दशको नेपाली पाठ्यपुस्तकमा पनि बोलाइ सिपको विकासका लागि मौखिक रूपमा विचार वा तर्क व्यक्त गर्ने खालका प्रश्नहरू राखिएका छन्। विचार वा तर्क सम्बन्धी अभ्यासलाई निम्नानुसार देखाउन सकिन्छ :

तालिका $\gamma$

विचार वा तर्कसम्बन्धी अभ्यासको स्थिति

\begin{tabular}{ll}
\hline पाठ & अभ्यास \\
\hline सन्दुक रुइत & देशका दुर्गम गाउँमा विकासको मुहान फुटाउन गर्नुपर्ने कामसम्बन्धी \\
थाड्का & थाड्का कलाको उत्कृष्ट रूप हो भन्ने विषयमा \\
म पानि सक्छु & मान्छेले कुनै एउटा विषयमा विशेषज्ञता हासिल गई्छ भन्ने सन्दर्भमा \\
प्रत्यागमन & कथाको शीर्षक र रामुको अवस्थाबारे \\
स्थानीयकरणभन्दा विश्वव्यापीकरण बेस & विश्वव्यापीकरण सम्पन्न र शक्तिशालीका पक्षमा रहेको विषयमा \\
लक्ष्मीपूजा & लालकी आमाले लक्ष्मीपूजाका सामान र मिठाइ नकिनेकी सन्दर्भमा
\end{tabular}

स्रोत : नेपाली कक्षा १०, २०७४

यस आधारमा पाठगत विषयवस्तुको र फरक विषयको विचार वा तर्क अभ्यास राखिएका छन्। पाठगत सड्ख्याका आधारमा हेर्दा १६ वटा पाठमध्ये ६ वटा पाठमा मात्र विचार वा तर्कसम्बन्धी अभ्यास राखिएका छन् । समग्र पाठमा विचार वा तर्कसम्बन्धी अभ्यासको प्रयोग स्थिति ३७.५ प्रतिशत देखिन्छ। विद्यार्थीमा मौखिक विचार वा तर्क शैलीको विकास गर्न अभ्यासहरू पर्याप्त देखिंदैन। विद्यार्थीलाई सहज किसिमे विचार राख्न प्रोत्साहन गर्ने खालका अभ्यास राख्नुपछ। शिक्षणीय दृष्टिले हेर्दा पाठअनुकूल वा अन्य विषयसम्बद्ध विचार वा तर्क गर्ने प्रश्नहरू थप्न सक्ने देखिन्छ। यिनै अभ्यासलाई आधार मानी अन्य पाठमा पनि शिक्षकले यस्ता अभ्यास गराउन सक्छन्।

\section{मौलिक वा सिर्जनात्मक वर्णनसम्बन्धी अभ्यास}

बोलाइ सिपको विकासका लागि मौखिक वा सिर्जनात्मक वर्णनसम्बन्धी अभ्यास राख्न सकिन्छ। शिक्षार्थीहरूले दैनिक जीवनमा देखेका, जानेका, अनुभव गरेका घटनाहरूको कक्षामा विवरण दिन लगाउनु पनि उपयुक्त हुन्छ (अधिकारी, २०६७, प्. प४ )। कक्षा वा पाठ्यपुस्तक सबै स्थितिमा मौलिक वा सिर्जनात्मक वर्णनको उपयोग गर्न सकिन्छ। पाठहरूमा मौलिक वा सिर्जनात्मक वर्णनसम्बन्धी अभ्यासको स्थिति यसप्रकार रहेको छ : 
तालिका $y$

मौलिक वा सिर्जनात्मक वर्णनसम्बन्धी अभ्यासको स्थिति

\begin{tabular}{ll}
\hline पाठ & अभ्यास \\
\hline जन्मभूमि & लक्ष्मणको चरित्रको व्याख्या \\
सन्दुक रुइत & आजैदेखि सुरु गर्न सक्ने सकरात्मक काम \\
म सडक बोल्दे छु & वरपरको सडकको अवस्था \\
\hline
\end{tabular}

स्रोत : नेपाली कक्षा १०, २०७४

तालिका $y$ का आधारमा हेर्दा १६ वटा पाठमध्ये जम्मा तीनवटा पाठमा मात्र मौलिक वा सिर्जनात्मक वर्णनसम्बन्धी अभ्यास राखिएको छ। पाठगत प्रयोगका आधारमा हेर्दा यो स्थिति १५.७५ प्रतिशत मात्र हो। यसर्थ विद्यार्थीको मौलिक र स्वतन्त्र वर्णन क्षमताको विकास गर्न अन्य पाठहरूमा पनि यस्तो अभ्यास अपेक्षित थियो। यी पाठहरूमा पनि पूर्णतः मौलिक खालका भन्दा पाठगत सम्बद्धताका आधारमा वर्णन गर्न सकिने अभ्यास राखिएको देखिन्छ। चित्र वर्णन, भावार्थ वर्णन, घटना वर्णन जस्ता अभ्यासहरू अत्यावश्यक रहने भए पनि यी पक्षलाई पाठ्यपुस्तकले समेट्न सकेको छैन। मौलिक वा सिर्जनात्मक वर्णनका लागि पाठगत सन्दर्भ बाहेकका विषयवस्तुलाई पनि उपयोग गर्नुपर्ने देखिन्छ।

\section{वाचनसम्बन्धी अभ्यास}

गति र यतिसहितको सान्दर्भिक उच्चारणले विद्यार्थीको बोलाइ सिप विकासमा सहयोग पुच्याउँछ। विशेषतः सस्वरवाचनले बोलाइ सिपसम्बन्धी अभ्यासमा स्थान पाएको देखिन्छ। कविता र अन्य विधाको वाचनका लागि पाठ्यपुस्तकमा राखिएका अभ्यासको स्थितिलाई निम्नानुसार प्रस्तुत गर्न सकिन्छ :

तालिका ६

वाचनसम्बन्धी अभ्यासको स्थिति

\begin{tabular}{ll}
\hline पाठ & अभ्यास \\
\hline सन्तुष्टि & कविताको १२ र १३ औं श्लोकको वाचन \\
प्रत्यागमन & ३० औँ अनुच्छेदको सस्वरवाचन \\
हाम्रो संस्कृति & चौथौं अनुच्छेदको सस्वरवाचन \\
\hline
\end{tabular}

स्रोत : नेपाली कक्षा १०, २०७४

तालिका ६ मा वाचनसम्बन्धी अभ्यासको स्थिति देखाइएको छ। सस्वरवाचनले बोलाइ र पढाइ दुबै सिपलाई प्रतिनिधित्व गर्ने कारण अभ्यासहरू कम राखिएको हुन सक्छ। पाठगत प्रयोगका आधारमा १६.७४ प्रतिशत पाठमा मात्र वाचनसम्बन्धी अभ्यास राखिएको देखिन्छ। बोलाइ र पढाइ दुबै सिपको विकासका लागि वाचनसम्बन्धी अभ्यासको उपयोग बढ़ गर्नु नै उपयुक्त हुन्छ। लयबद्ध वाचनका लागि कविता र सस्वरवाचनका लागि सबै विधाहरूलाई उपयोग गर्न सकिने भए पनि यस पाठ्यपुस्तकमा सो कुरालाई आत्मसात् गर्न सकिएको छैन । 


\section{कुराकानी, संवाद र अभिनयसम्बन्धी अभ्यास}

स्वाभाविक परिवेशमा बोलाइ सिपको विकासका लागि कुराकानी, संवाद र अभिनयसम्बन्धी अभ्यासको प्रभावकारी उपयोग गर्न सकिन्छ। कक्षा दशको पाठ्यपुस्तकमा प्रयुक्त यस्ता अभ्यासलाई निम्नानुसार देखाइएको छ :

तालिका $७$

कुराकानी, संवाद र अभिनयसम्बन्धी अभ्यासको स्थिति

\begin{tabular}{ll}
\hline पाठ & अभ्यास \\
\hline सन्दुक रुइत & सन्दुकलाई पढ्न पठाउन उनका बाबुआमाले गरेका कुराकानीको अभिनयात्मक संवाद \\
वर्षा & वर्षा ऋतुका बारेमा संवाद \\
हाम्रो संस्कृति & भिन्न संस्कृतिका साथीहरू बिचको हाउभाउसहितको कुराकानी \\
जयभुंडी & भुँडीकै समस्याबाट उब्जिएका युद्धका बारेमा हाउभाउसहितको संवाद \\
माउजङ बाबुसाहेबको कोट & पाठ्यकथा कस्तो लाग्यो भन्ने विषयमा संवाद \\
\hline
\end{tabular}

स्रोत : नेपाली कक्षा १०, २०७४।

तालिका ७ का आधारमा पाँचवटा पाठमा कुराकानी, संवाद र अभिनयसम्बन्धी अभ्यास राखिएको पाइन्छ। पाठगत वितरणका आधारमा हेर्दा यो ३१. २५ प्रतिशत हुन आउँछ। उल्लिखित पाठहरूमा दुईवटा सामान्य संवाद र तीनवटा अभिनय वा हाउभाउसहितको अभ्यास रहेको देखिन्छ। भाषिक सम्प्रेषण र बोलाइको स्वाभाविकताको लागि कुराकानी र संवाद नै बढी उपयोगी हुन्छ। पाठकै चरित्रका साथसाथै अन्य विषय सन्दर्भ लिएर पनि यस्तो अभ्यास गराउनु राम्रो देखिन्छ।

\section{छलफल सम्बन्धी अभ्यास}

दुई वा सोभन्दा बढ़ी व्यक्तिहरू बिच हुने विचारको पारस्परिक सम्बन्ध र सहयोगलाई छलफल भनिन्छ। बोलाइ सिपको विकासमा सहयोग पुच्याउने उच्च स्तरीय कार्यकलापको रूपमा यसलाई लिइन्छ। पाठ्यपुस्तककै विषय वा अन्य विषयमा विद्यार्थीलाई छलफलमा सहभागी गराउन सकिन्छ। कक्षा दशको पाठ्यपुस्तकमा पनि बोलाइ सिपको विकास र परीक्षणका लागि छलफल सम्बन्धी अभ्यासहरू राखिएका छन् । यस्ता अभ्यासलाई निम्नानुसार प्रस्तुत गर्न सकिन्छ : 
तालिका द

छलफलसम्बन्धी अभ्यासको स्थिति

\begin{tabular}{ll}
\hline पाठ & अभ्यास \\
\hline म पनि सक्छु & अपाड्गता भएका व्यक्तिलाई दया होइन, अवसर दिनुपछ भन्ने विषयमा कक्षा छलफल \\
व्यापारिक चिठी & साहित्यिक किताब पढ्दा हुने फाइदा \\
& अतिरिक्त साहित्यिक किताब पढ्दा परीक्षामा पर्ने प्रभाव \\
& व्यापारिक चिठी पढ़नु पर्नाको कारण \\
वर्षा & वर्षा ऋतुमा देखिने परिवर्तनका बारेमा समूह छलफल \\
स्थानीयकरणभन्दा & समाजमा विश्वव्यापीकरणको प्रभाव र वादविवादका नयाँ विषयका बारेमा छलफल \\
विश्वव्यापीकरण बेस & \\
लक्ष्मीपूजा & जुवा, तास खेल्नु हुन्न भन्ने विषयमा छलफल \\
क्लारा जेटकिन & विवाहपछि, पतिको थर राख्ने चलनका बारे छलफल \\
जय भुँडी & जय भुँडी निबन्धको शीर्षक उपयुक्तताबारे छलफल \\
टीका & एकाड्की लेखनको समयमा पहिले जस्तो लाखौं युवा विदेसिने गरेका भए लेखकले एकाङ्कीमा के \\
& कस्ता संवादहरू परिवर्तन गर्थे भन्ने विषयमा छलफल \\
\hline
\end{tabular}

स्रोत : नेपाली कक्षा १०, २०७४

तालिका $\sqsubset$ मा छलफलसम्बन्धी अभ्यासको स्थिति देखाइएको छ। ४०० प्रतिशत पाठहरूमा छलफलसम्बन्धी राखेको पाइयो। 'व्यापारिक चिठी' पाठमा छलफलसम्बन्धी तीनवटा अभ्यास राखिएको छ भने 'स्थानीयकरणभन्दा विश्वव्यापीकरण बेस' पाठमा दुईवटा अभ्यास उपयोग गरिएको छ। बाँकी छवटा पाठमा छलफलसम्बन्धी एकएकवटा अभ्यास राखिएको छ। पाठकै केन्द्रीयतामा छलफलका अभ्यासहरू निर्धारण भएको पाइन्छ। 'क्लारा जेटकिन' पाठमा दिइएको छलफलको विषय असान्दर्भिक देखिन्छ। ससाना विषय दिएर सबै पाठहरूमा छलफल सम्बन्धी अभ्यास राख्न सके बोलाइ सिपको विकास हुन्छ। सामूहिक छलफललाई परीक्षण गर्ने आधारहरू पनि पाठ्यपुस्तकमा नमुनाको रूपमा राखेको भए यसको उपयोग र परीक्षणमा सहजता हुने थियो ।

\section{बोधात्मक प्रश्नोत्तरसम्बन्धी अभ्यास}

पाठगत मौखिक प्रश्नोत्तरलाई यहाँ बोधात्मक प्रश्नोत्तरको रूपमा लिएको छ। निर्धारित पाठ्यविषय वा अनुच्छेदबाट मौखिक रूपमा प्रश्नोत्तर गराई विद्यार्थीमा बोलाइ सिपको विकास गर्ने लक्ष्य राखिएको हुन्छ। कक्षा दशको नेपाली भाषा पाठ्यपुस्तकमा राखिएका यस प्रकृतिका प्रश्नलाई निम्नानुसार देखाउन सकिन्छ : 
कक्षा दशको नेपाली भाषा पाठयपुस्तकमा बोलाइ सिपको अभ्यास/ 157

तालिका $\rho$

बोधात्मक प्रश्नोत्तरसम्बन्धी अभ्यासको स्थिति

\begin{tabular}{ll}
\hline पाठ & अभ्यास \\
\hline थाड्का & थाङ्का लेख्ने कपडा कसरी तयार हुन्छ भन्ने प्रश्न \\
वर्षा & वर्षा कविताका लेखक, ऋतुमा पर्ने महिना, वर्षा आउने स्थिति र मुस्कुराउने प्रवृत्तिबारे प्रश्न \\
क्लारा जेटकिन & क्लारा जेटकिनको वैवाहिक जीवनबारे \\
म सडक बोल्दे छु & कविताको चौथो परिच्छेदले भन्न खोजेको कुराको वर्णन \\
\hline
\end{tabular}

स्रोत : नेपाली कक्षा १०, २०७४

तालिका $९$ मा बोधात्मक प्रश्नोत्तरसम्बन्धी अभ्यासको स्थिति देखाइएको छ। यस आधारमा $४$ वटा पाठमा मात्र मौखिक प्रश्नोत्तरसम्बन्धी प्रश्नोत्तर राखिएको छ। बोलाइ सिपको विकासमा प्रारम्भिकदेखि माथिल्ला कक्षासम्म प्रश्नोत्तरको मुख्य भूमिका हुने कारण यस्ता अभ्यासलाई पाठ्यपुस्तकले समेट्नुपर्ने देखिन्छ।

\section{निष्कर्ष}

भाषा पाठयपुस्तक भाषिक सिपहरूमा सक्षमता ल्याउने महत्त्वपूर्ण साधन हो। विद्यालयीय शिक्षणमा पाठ्यपुस्तककै आधारमा सिपहरूमा अभ्यस्तता सिर्जना गरिन्छ। भाषा पाठ्यपुस्तकमा राखिएका नमुना अभ्यासहरूमध्ये बोलाइ सिपको अभ्यासमा के कस्ता पक्षहरू समेटिएका रहेछ्छ् भनेर अध्ययन गरी परिणाम निकालिएको छ। कक्षा दशको नेपाली पाठ्यपुस्तकमा जम्मा २९४ वटा सिपगत नमुना अभ्यासहरू राखिएका छन् र त्यसमध्ये २२.७६ प्रतिशत अभ्यास बोलाइ सिपसँग सम्बन्धित छन्। बोलाइ सिप विकासका लागि सबैभन्दा बढी उच्चारणसंग सम्बद्ध अभ्यासलाई जोड दिएको निष्कर्ष निकालिएको छ। उच्चारणगत अभ्यासमा दिइएका शब्दहरूमध्ये सबैभन्दा बढी माउजड बाबुसाहेबको कथामा पाइएको छ। यसपछि शब्दार्थ र वाक्यमा प्रयोगसम्बन्धी अभ्यासलाई प्राथमिकता दिइएको छ। यस्तो अभ्यास ४.५१ देखि २७.७१ प्रतिशतसम्म रहेको छ। पू० प्रतिशत पाठहरूमा छलफलसम्बन्धी अभ्यास राखिएकाले उच्चारण र वाक्यमा प्रयोगपछि, यही अभ्यासले प्राथमिकता पाएको देखिन्छ। ६ वटा पाठमा विचार वा तर्कसम्बन्धी अभ्यास दिइएको छ। मौलिक वर्णन, वाचन, कुराकानी, संवाद र अभिनय, प्रश्नोत्तर आदि पक्षसंग सम्बन्धित अभ्यासमा न्यूनता देखिएको छ। वर्तमान कक्षा दशको नेपाली भाषा पाठ्यपुस्तकले बोलाइ सिपको विकासमा विविधता ल्याउन खोजे पनि चित्र वर्णन, घटना वर्णन, शाब्दिक निबन्ध आदि पक्षले स्थान नपाउनु कमजोर पक्ष हो। बोलाइ सिपको अभ्यासमा पूर्व ज्ञान र नवप्रवर्धनात्मक अभ्यासलाई विशेष जोड दिइएको छ।

भाषा पाठ्यपुस्तक शिक्षण सिकाइको आधिकारिक स्रोत सामग्री हो। भाषा शिक्षकले पाठ्यपुस्तकलाई मुख्य साधन मानी शिक्षण सच्चालन गर्दछ् । यसर्थ सिपगत अभ्यासलाई पहिचान गरी पाठगत सन्दर्भअनुकूल शिक्षण गतिविधि अगाडि बढाउन यस अध्ययनबाट प्राप्त निष्कर्षले सहयोग पुच्याउनेछ । त्यस्तैगरी कक्षाकोठामा बोलाइ सिपको कार्यकलाप सन्चालनार्थ आवश्यक पक्षको किटान र उपयोगमा सहजता सिर्जना हुनेछ। यस अध्ययनबाट प्राप्त निष्कर्षले भाषा शिक्षणमा संलग्न व्यक्तिका साथसाथै पाठ्यक्रम निर्माता, पाठ्यपुस्तक लेखक तथा भाषिक सिपको परीक्षणमा अध्ययन अनुसन्धान गर्न खोज्नेहरूका लागि उपयोगी हुने विश्वास लिइएको छ। 


\section{सन्दर्भसामग्री सूची}

अधिकारी, हेमाड्गराज (२०६७), नेपाली भाषा शिक्षण, काठमाडौं : विद्यार्थी पुस्तक भण्डार ।

पाठ्यक्रम विकास केन्द्र (२०७४), नेपाली कक्षा १०, सानोठिमी : जनक शिक्षा सामग्री केन्द्र।

पाठ्यक्रम विकास केन्द्र (२०७१), माध्यमिक शिक्षा पाठ्यक्रम ९-१०, सानोठिमी : जनक शिक्षा सामग्री केन्द्र।

पौडेल, माधवप्रसाद (२०६४), भाषिक मूल्याड्कनका प्रयोगात्मक सन्दर्भहरू, सम्प्रेषण, वर्ष $४$, अड्क $\curlyvee$,

पृ. ७२-६१ ।

ब्रोवन, एच.डी. (सन् २००४), ल्याड्ग्वेज एसेसमेन्ट, लन्डन : लड्म्यान ।

ल्याडो, रबर्ट (सन् १९६४), ल्याङ्ववेज टेस्टिङ; लन्डन : लङ्म्यान ।

वाइर, सि.जे. (सन् १९६६), कम्युनिकेटिभ ल्याइ्गवेज टेस्टिङ; हेमेल हेम्प्सटेड : प्रेन्टिस हल ।

हिटन, जे. बी. (सन् १९९०), राइटिङ इड़लिस ल्याड्ग्वेज टेस्ट्स, लन्डन : लड्म्यान । 